Research article

\title{
Hydrogeological identification of the Welaran Watershed Karangsambung based on descriptive-qualitative method
}

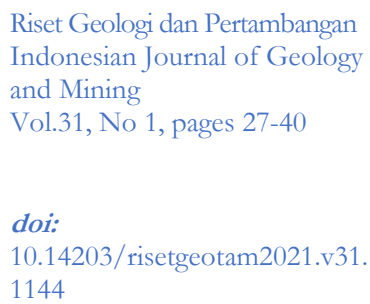

Cortesponding author Nandian Mareta

E-mail address:

nandianthea@gmail.com

Article history Received 28 Dec 2020

Revised 22 Jun 2021

Accepted 23 Jun 2021

C2021 Pusat Penelitian Geoteknologi - Lembaga Ilmu Pengetahuan Indonesia

This is an open access article under the CC BY-NC-ND license

(http://creativecommons.org/1 icenses/by-nc-nd/4.0/).

\author{
Nandian Mareta ${ }^{12 *}$, R. Fajar Lubis¹, Boy Yoseph CSSSA $^{3}$, \\ M. Sapari Dwi Hadian ${ }^{3}$ \\ ${ }^{1}$ Research Center for Geotechnology, Indonesian Institute of Sciences, Bandung \\ ${ }^{2}$ Master student (S-2), Faculty of Geological Engineering, Padjadjaran University, \\ Bandung \\ ${ }^{3}$ Faculty of Geological Engineering, Padjadjaran University, Bandung
}

\begin{abstract}
The Welaran Watershed in the Karangsambung area is hydrogeologically interesting because of its morphology, "U" shaped morphology like an amphitheater with the lithology consisting of tertiary to quarternary rocks. The character of Welaran river is an intermittent river that watery during the rainy season and dry during the dry season. This study intended to identify and determine the general hydrogeological condition of the Welaran Watershed on a scale of 1:20.000. This study applies a descriptive-qualitative research method. The steps used are hydrogeological analysis and water balance. The results obtained indicate that the hydrogeological conditions of the area affect the character of the rivers in the Welaran Watershed causing them to become intermittent rivers.
\end{abstract}

\section{INTRODUCTION}

The Welaran Watershed in Karangsambung is hydrogeologically interesting because of its " $U$ " shape morphology that similar to an amphitheater. The appearance of the amphitheater in this area is known in the literature as the Welaran Watershed (Raharjo et al., 2015). Welaran Watershed is the upstream part of the Luk Ulo watershed; the Welaran river is the main river that tributary to the Luk Ulo river. The surrounding hills of the Welaran Watershed that becomes the boundary are Paras hills in the north, Dliwang hills in the east, and Waturanda hills in the south, whereas the Luk Ulo river becomes the west border of this watershed.

Drought is a condition that occurs almost every year in the Welaran Watershed during the dry season (Figure 1). The two factors that cause this frequent water shortage are the lithology that consists of tertiary to quarternary rocks and rainfall in this area. The rivers in the Welaran Watershed is intermittent river type that watery during the rainy season and dry in the dry season (Figure 2). 

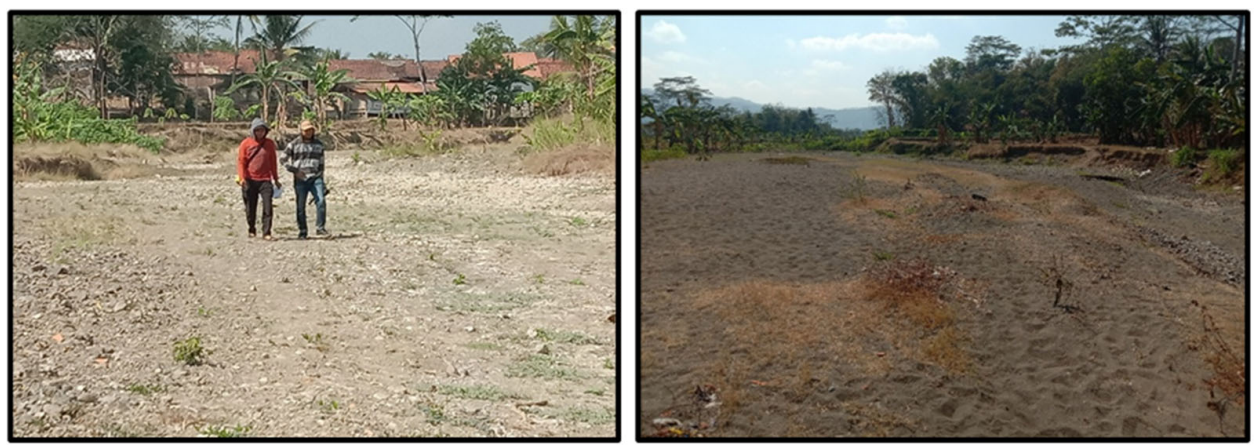

Figure 1. The condition of the Welaran river, which is dry during the dry season (taken on September 18, 2019).
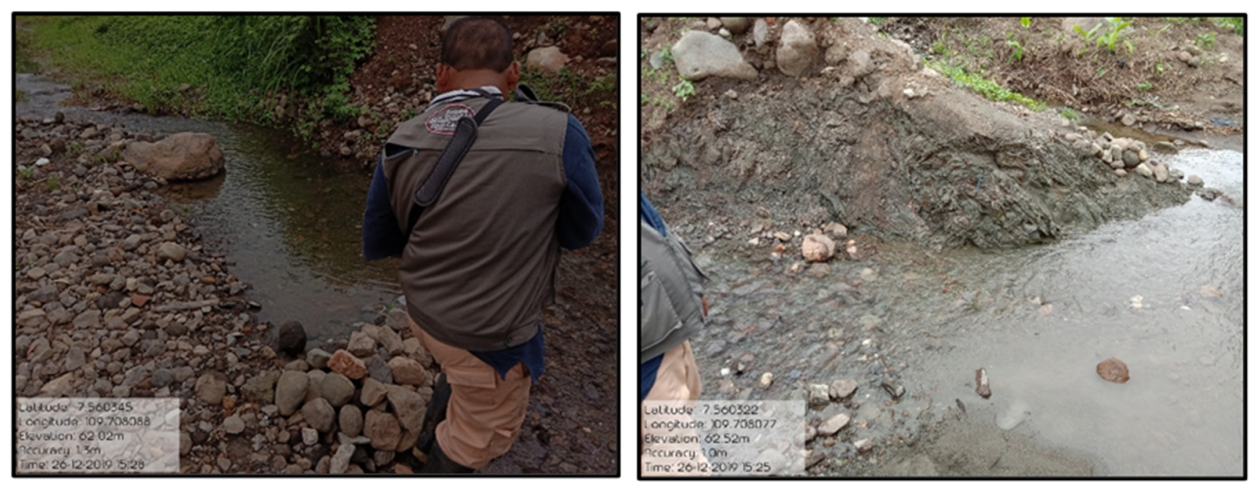

Figure 2. Left, the condition of the Welaran river, which is filled with water as the rainy season begins; right, the claystone outcrop of the Karangsambung formation in the Welaran river that filled with water (taken on December 26, 2019).

This study examines various factors, such as rainfall, geological conditions, and river bodies (watershed) as natural water storage areas to explain the character of the rivers. The calculation of the water from these various factors provides qualitative data regarding the characteristics of the Welaran Watershed, especially on its hydrogeology condition.

\section{LOCATION}

Welaran Watershed is administratively part of the Karangsambung District, Kebumen Regency, Central Java (Figure 3), located at coordinates $7^{\circ} 32^{\prime} 13^{\prime \prime}-7^{\circ} 34^{\prime} 32^{\prime \prime}$ South Latitude and $109^{\circ} 40^{\prime} 00^{\prime \prime}$ - 109 $43^{\prime} 10^{\prime \prime}$ East Longitude. This watershed is spread over an area of $17.65 \mathrm{~km}^{2}$ (1765 $\mathrm{Ha}$ ). Karangsambung District administratively consists of 14 villages with an area of $6515 \mathrm{Ha}$. To the west, the Welaran Watershed is bordered by the Luk Ulo river. The rivers that are part of the Welaran Watershed include: 1). K. Welaran, 2). K. Sangga, 3). K. Depok, 4). K. Pelikon, 5). K. Salak, 6). K. Jirek, 7). K.Sana, 8). K.Village, 9). K.Short, 10). K. Sawuh, 11). K. Curug, 12). K. Poh, 13). K. Sadang, 14). K.Milk, and 15). K. Wuluh.

\section{GEOLOGY DAN HYDROGEOLOGY}

Based on field observations and topography, the geomorphology of the research area (Figure 3) can be divided into two units, which are: 


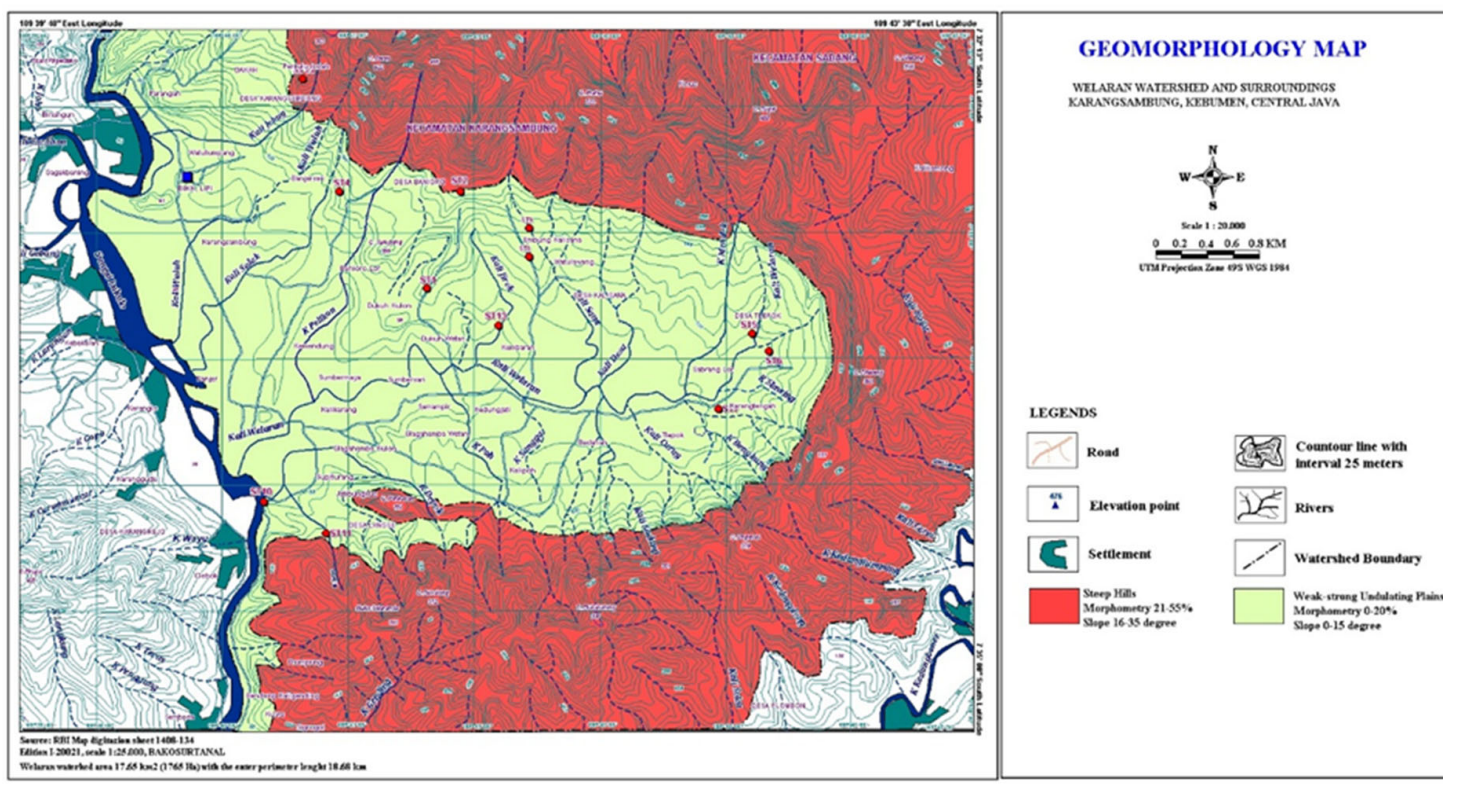

Figure 3. The Welaran Watershed research location with an area of 1765 hectares.

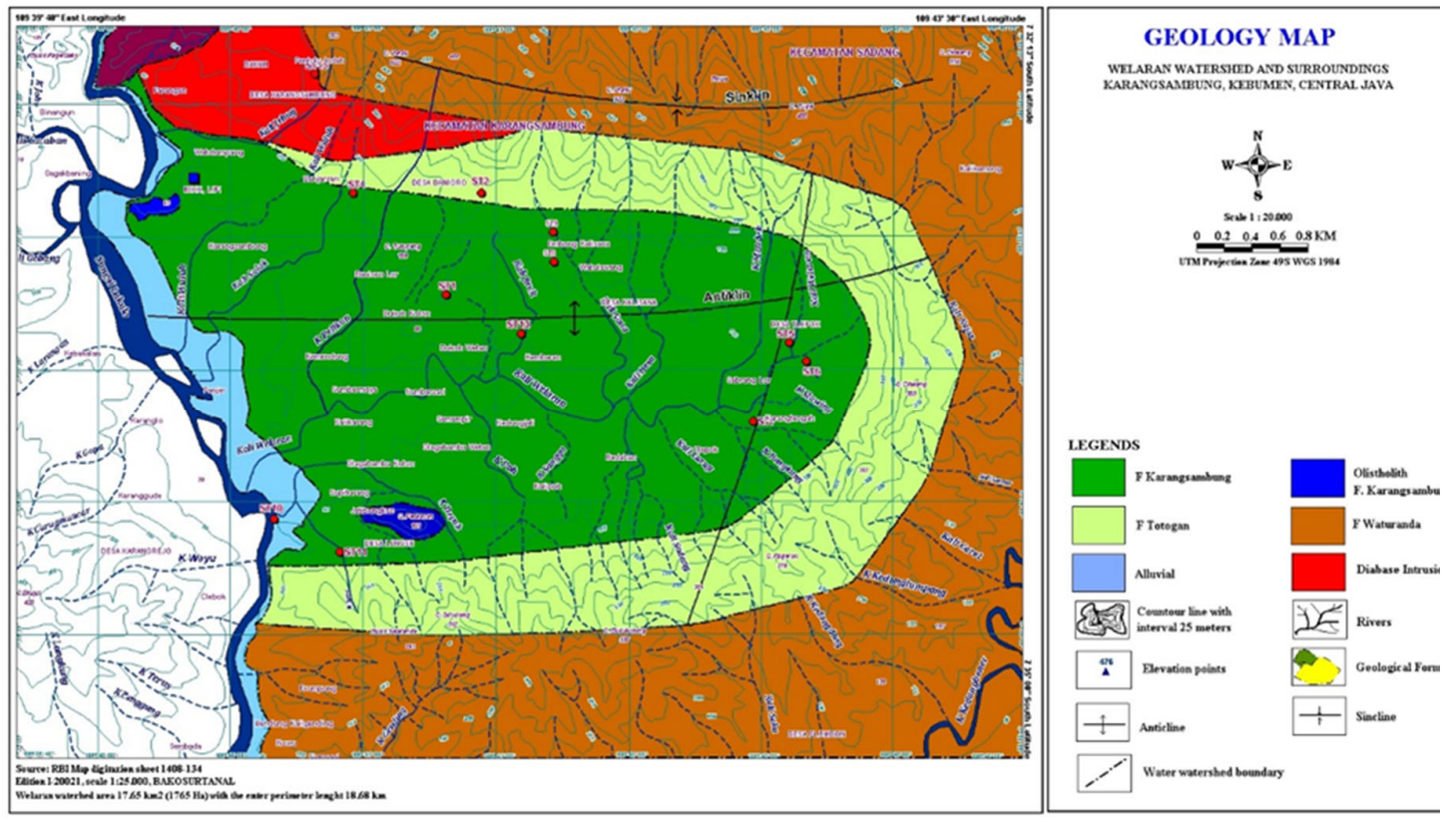

Figure 4. Geological map of Welaran Watershed research area and its surroundings (modification from Asikin et al., 1992 op.cit Mareta \& Raharjo, 2017).

\section{a. Weak-Strong Undulating Plain Unit}

This morphology is located in the middle of the research area with an area of $1.260 \mathrm{Ha}$ (71.39\%). The morphometry unit of this undulating plain is $0-12 \%$ with a slope of $1-15^{\circ}$ and altitude of 20 to less than 100 meters above sea level (masl). Some of them are flat, and the others are wavy weak - strong undulating. The lithology constituent of this morphology is claystones of the Karangsambung Formation and the Totogan Formation. Weathering is quite 
intensive and produces relatively thick soil with a clay texture. Generally, the land is occupied as a village and rainfed rice fields. The weak - strong undulating morphology is strongly influenced by the geological structures developed in this area. The valleys of the horseshoe area and the undulating plains of the western part of the Luk Ulo river are controlled by a fold structure, with the crest of the fold axis is on this morphology. In the past, the wavy plains in this place were a peak of the anticline that now become a plain. It is closely related to the inverse topography event.

\section{b. Steep Hills Unit}

This unit forms a horseshoe morphology the peak of the range are G. Brujul (428 masl), G. Selorondo (263 masl), G. Bulukuning (337 masl), G. Pagerori (316 masl), G. Dliwang (353 masl), G. Gandul (547 masl), G. Tugel (488 masl), G. Perahu (522 masl), and G. Paras (510 masl). These hills extend from west to east and bending to the north at G. Dliwang. In this unit, the anticline and syncline fold structures were incised and experienced a topographic reversal. The main lithology constituent is a breccia with sandstone insertion of the Waturanda Formation. The morphometric of this Steep Hills morphology unit is $21-55 \%$ with a slope of $16^{\circ}-35^{\circ}$ with an altitude of 100-500 masl. This area extends in a $505 \mathrm{Ha}(28,61 \%)$ area. Weathering is relatively intensive and produces loamy sand textured soil. The appearance of the half-circular hills like a horseshoe is controlled by a submerged fold structure, in which the peak of the fold (anticline) has eroded and become a valley.

The regional geology of Karangsambung (Figure 4) where the Welaran Watershed is located has been studied by several resercher (Harloff, 1933; Tjia, 1966 op.cit Suparka, 1988; Asikin, 1974; Suparka, 1988; Wakita et al., 1994; Harsolumakso, 1996; Yuwono, 1997; and Prasetyadi, 2007 op.cit Setiawan et al., 2011).

Several researchers have compiled a stratigraphic sequence of the Karangsambung area. The stratigraphic order from old to young is; 1). Luk Ulo Melange Complex, 2). Karangsambung Formation, 3). Totogan Formation, 4). Diabase and Basalt Intrusion, 5). Waturanda Formation, 6). Penosogan Formation, 7). Halang Formation, 8). Peniron Formation, 9). Aluviall (Asikin et al., 1992 Op.cit Mareta dan Raharjo., 2017). The lithology exposed in the Welaran Watershed consist of five formations and alluvial deposit, in order from old to young (Figure 5):

1. The constituent components of the olistrostrome of the Karangsambung Formation are rock blocks (olistholiths) that float in a claystone matrix.

2. Karangsambung Formation, this rock formation consists of gray claystone containing iron concretions, nummulite limestones, conglomerates, and laminated polymic quartz sandstones. Greywacke sandstone to black claystone shows a scaly structure that sliced in all directions with an almost even surface. The geology structure is a result of the underwater depositional mechanism of a large volume of the material. The deposition mechanism of the olistrostrome of the Karangsambung Formation was by mixing of the materials due to submarine landslides. Based on the age of the planktonic foraminifera, this formation is formed during Middle Eocene to Late Eocene (45-36 million).

3. Totogan Formation has similar characteristics to the Karangsambung Formation, characterized by lithology in brown and sometimes purple claystone with a scaly structure. There are also limestone fragments trapped in sandstone, mudstone, fossilized limestone, and igneous rocks. The depositional mechanism of the Totogan Formation, which is olistrostrome, is the same as the Karangsambung Formation. The age of this formation is Oligocene (36-25 million). 
4. The Diabase Intrusion intruded the Karangsambung Formation and, in several order places, also intruded the Totogan Formation. Diabase is an intrusive igneous rock that formed dike (G. Bujil) and sill (G. Parang) in the studied area. A pillow lava flow is found in some parts, but it is more andesitic with a coarser texture than pillow lava in the melange complex. This intrusive rock group has an archipelagic tholeiite affinity which was a result of underwater volcanism with an eruption around Mount Parangan (hills)-Dakah (Yuwono., 1997 op. cit Setiawan et al., 2011). According to Soeria-Atmadja et al. (1991), the K-Ar radiometric dating of G. Parang Diabase results is 39-26 million years old or around Eocene-Oligocene, that identical to the age range of Karangsambung Formation-Totogan.

5. Waturanda Formation consists of volcanic breccia and wacke sandstones with claystone inserts at the top. The sandstone is gray with medium-coarse grains composed of igneous rock fragments and obsidian. The age of this formation is estimated to be Miocene (25.2-5.2 million).

6. Alluvial (fluvial), consisting of clay, sand, gravel, and unconsolidated gravel that has the youngest age of Holocene-Recent.

Among the five formations in the Welaran Watershed, Waturanda and Alluvium Formation is suspected as the most potential as aquifers because of the lithology conditions, which have greater porosity and permeability. (BBWS Serayu-Opak, 2003). The research area of the Welaran Watershed is included as an area that is not a groundwater basin. According to the Hydrogeological Map of Indonesia, the scale of 1:250.000 issued by the Directorate of Environmental Geology (1985), the Welaran Watershed research area consists of two types of aquifers, that are:

1. Aquifers with low productivity occupy the Waturanda Formation. These aquifers generally have low to very low continuity, occurs in a local area, and limited groundwater available in valley areas or weathering zones.

2. Areas with scarce groundwater occupy the Karangsambung Formation, Totogan Formation, and Diabase.

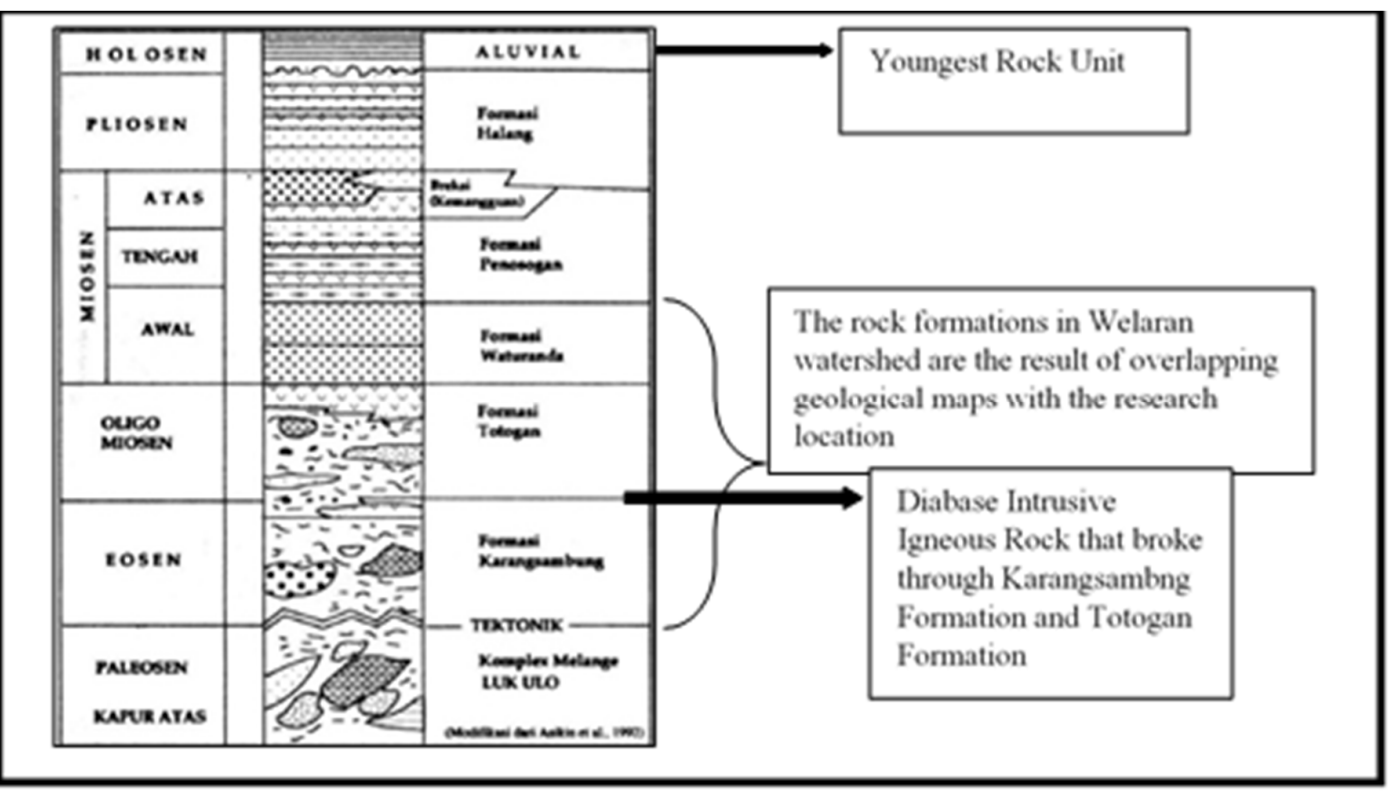

Figure 5. Stratigraphic sequences in the research area and stratigraphic columns (modification from Asikin et al., 1992 Op.cit Mareta \& Raharjo., 2017). 


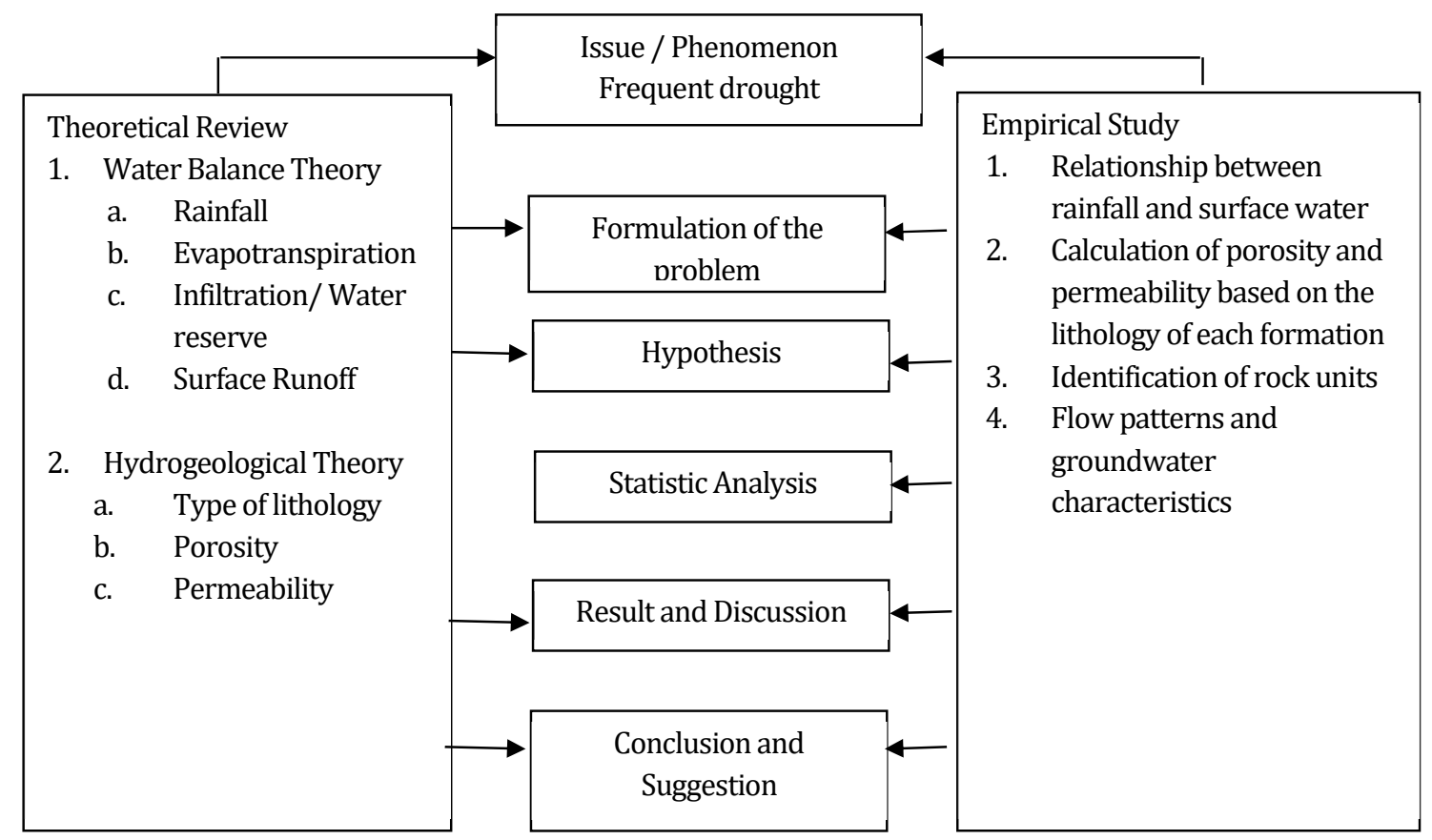

Figure 6. Research framework flow chart.

Porosity analysis derived from measurements on the rock formations from the Welaran Watershed; 10 samples were taken from each formation for laboratory analysis (bulk sample). Each sample was tested for its porosity percentage by sun-drying (under the sun's heat), then it was weighted for about 1000 grams. After that, the sample was saturated with water for 24 hours. Then the weight of the sample was re-weighed to determine the weight after being saturated with water for 24 hours.

\section{RESULT AND DISCUSSION}

\section{Relationship between Rainfall and Surface Water}

The comparison between monthly rainfall and surface water is taken from the comparison of rainfall with the water level in the Welaran river, which shows an interconnected pattern (Table 1). When it rains, some of the rainwater will turn into runoff which can be seen at the river's height in a watershed outlet. The amount of rainfall in Karangsambung, Kebumen in one year from September 2019 to September 2020 was $3586 \mathrm{~mm}$, while the total water level in Welaran river in the same period was $2198.52 \mathrm{~cm}$. The water level in the Welaran river describes the amount of runoff that occurs in the watershed area. The amount of runoff is $0.62 \%$ (Figures 7 and 8).

\section{Calculation of Porosity and Permeability based on the Lithology of Each Formation}

The bulk test of rock samples showed the largest weight gain was recorded in Alluvial by $22.3 \%$, and the smallest was in Diabase Intrusion by $0.213 \%$ (Table 2). The weight gain from the largest to the smallest, respectively shown by 1 . Alluvial (22.3\%); 2 . Waturanda Formation (14.4\%); 3. Totogan Formation (7.6\%); 4. Karangsambung Formation (6.7\%); and 5. Diabase Intrusion (0.213\%). The porosity percentage of the bulk samples (Tabel 3) shows that the rocks have the ability to pass water according to criteria. The criteria used to classify the permeability are porosity value less than $10 \%$ considered as poor permeability, porosity greater than $10 \%$ as good permeability (Koesoemadinata, 1980., Op.cit Aulia., et al., 2020). 
Table 1. Relationship between rainfall and high water level Welaran River.

\begin{tabular}{clrc}
\hline No & \multicolumn{1}{c}{ Month } & $\begin{array}{c}\text { Rainfall } \\
(\mathbf{m m})\end{array}$ & $\begin{array}{c}\text { Water level in Welaran } \\
\text { River (cm) }\end{array}$ \\
\hline 1 & September 1, 2019 & 47 & 21.22 \\
2 & October 2, 2019 & 160 & 99.2 \\
3 & November 3, 2019 & 370 & 229.4 \\
4 & December 4, 2019 & 380 & 235.6 \\
5 & January 5, 2020 & 310 & 192.2 \\
6 & February 6, 2020 & 378 & 234.36 \\
7 & March 7, 2020 & 355 & 220.1 \\
8 & April 8, 2020 & 573 & 355.26 \\
9 & May 9, 2020 & 540 & 334.8 \\
10 & June 10, 2020 & 200 & 124 \\
11 & July 11, 2020 & 90 & 55.8 \\
12 & August 12, 2020 & 92 & 57.04 \\
13 & September 13, 2020 & 98 & 60.76 \\
\hline
\end{tabular}

Table 2. Bulk sample test result on all lithology units in the Welaran Watershed.

\begin{tabular}{llcccc}
\hline No & \multicolumn{1}{c}{ Rock Units } & $\begin{array}{c}\text { Initial } \\
\text { Weight } \\
\text { (grams) }\end{array}$ & $\begin{array}{c}\text { Final } \\
\text { Weight } \\
\text { (grams) }\end{array}$ & $\begin{array}{c}\text { Weight } \\
\text { Gain } \\
\text { (grams) }\end{array}$ & $\begin{array}{c}\text { Weight } \\
\text { Percentage }\end{array}$ \\
\hline 1 & F. Karangsambung & 1000 & 1000.0670 & 0.0670 & $6.70 \%$ \\
2 & F. Totogan & 1000 & 1000.0716 & 0.0716 & $7.16 \%$ \\
3 & Diabase Intrusion & 1000 & 1000.0213 & 0.0213 & $2.13 \%$ \\
4 & F. Waturanda & 1000 & 1000.1450 & 0.1450 & $14.5 \%$ \\
5 & Alluvial & 1000 & 1000.2230 & 0.2230 & $22.3 \%$ \\
\hline
\end{tabular}

Table 3. Percentage of porosity and permeability of each rock unit in the Welaran Watershed.

\begin{tabular}{clccc}
\hline No & \multicolumn{1}{c}{ Rock Units } & $\begin{array}{c}\text { Percentage of } \\
\text { Porosity }\end{array}$ & Permeability & $\begin{array}{c}\text { Area } \\
\mathbf{( k m}^{2} \mathbf{~}\end{array}$ \\
\hline 1 & F. Karangsambung & $6.70 \%$ & Poor & 10 \\
2 & F. Totogan & $7.16 \%$ & Poor & 2.11 \\
3 & Diabase Intrusion & $2.13 \%$ & Poor & 3.18 \\
4 & F. Waturanda & $14.50 \%$ & Good & 1.48 \\
5 & Alluvial & $22.30 \%$ & Good & 0.88 \\
\hline \multicolumn{2}{c}{ Total } & & & 17.65 \\
\hline
\end{tabular}




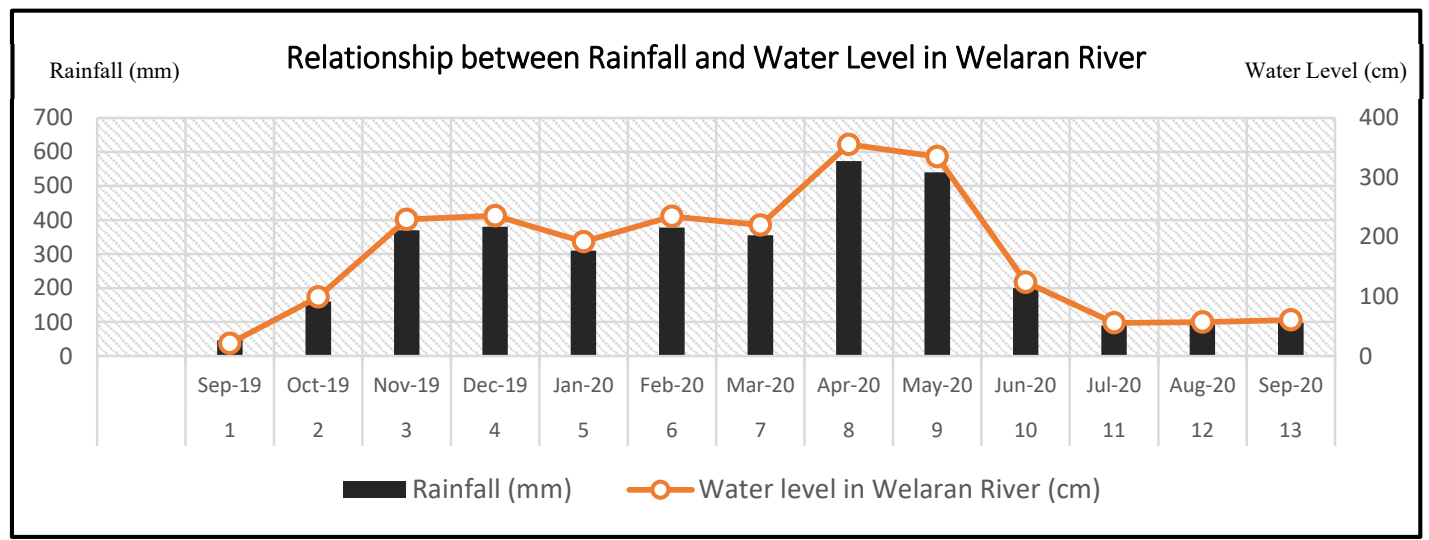

Figure 7. Graph of Relationship between rainfall and water level in the Welaran River.

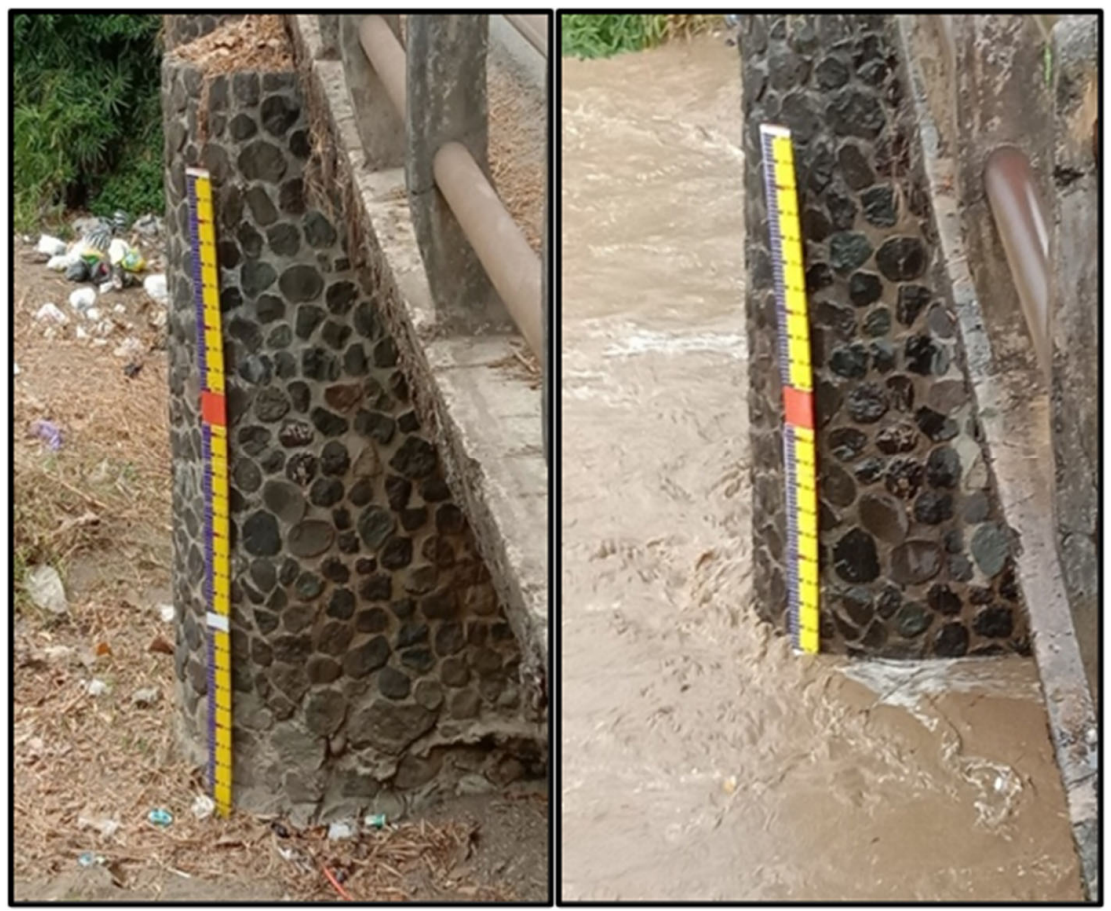

Figure 8. Left, the water level in Welaran River at the end of the dry season on September 3, 2019; right, the water level in Welaran River when entering the rainy season on December 24, 2019.

\section{Identification of Lithology Units}

The Welaran Watershed is composed of five lithology units. The Waturanda Formation and alluvial are two units that, based on the analysis, have good porosity and permeability parameters among the others units. The detailed geology of the research area are:

1. Karangsambung Formation occupies the largest area in the watershed (56.66\%) of the total watershed area $\left(10 \mathrm{~km}^{2}\right)$. It is predominantly composed of a mass of scaly claystone, the porosity is $6.67 \%$, and the permeability is poor. 
2. Totogan Formation consists of scaly claystone breccia and olistholith; it occupies a smaller area than the Karangsambung Formation of $2.11 \mathrm{~km}^{2}(12 \%)$. It is predominantly composed of a mass of scaly claystone, the porosity is $7.16 \%$, and the permeability is poor.

3. Diabase Intrusion consists of diabase, massive, compacted, solid igneous rock. The area of this formation is $3.18 \mathrm{~km}^{2}(18 \%)$, the porosity is $2.13 \%$, and the permeability poor.

4. The Waturanda Formation consists of volcanic breccia and sandstone with a thickness almost identical to the claystone insertion. The area of this rock formation is $1.48 \mathrm{~km}^{2}(9 \%)$, the porosity is $14.5 \%$, and the permeability is good.

5. Alluvial consists of unconsolidated rock, gravel to lumps grain size. The area of this rock formation is $0,88 \mathrm{~km}^{2}(5 \%)$, the porosity is $22,3 \%$, and the permeability is good.

The area of impermeable rock units in the Welaran Watershed is $15.29 \mathrm{~km}^{2}(86.63 \%)$ of the total area occupied by the Karangsambung Formation, Totogan Formation, and Diabase Intrusion. The area that can pass water (permeable) is $2.36 \mathrm{~km}^{2}(13.37 \%$ ) occupied by Waturanda Formation and Alluvial. Most of the rocks in the Welaran Watershed are rocks that are difficult to pass water so that the absorption (infiltration) of rainwater into the rocks when it rains becomes difficult. Most of the rain that falls will become surface runoff.

\section{Condition of Dug Wells and Groundwater Flow Pattern}

Data retrieval for the dug wells was done scattered throughout the Welaran basin at 33 sampling points (sample code SG). Among them, there are 11 spring data coded with MA. All points are plotted on the observation map (Figure 9).

The wells data recorded includes the coordinates, depth of the well, $\mathrm{pH}$ condition of the water, and condition of the well during the dry season, whether it is watery or dry. The springs' data includes the coordinates and $\mathrm{pH}$ of the water. The data was processed using Surfer software to describe the direction of the groundwater flow pattern (Figure 10). Based on Surfer's analysis, the movement of

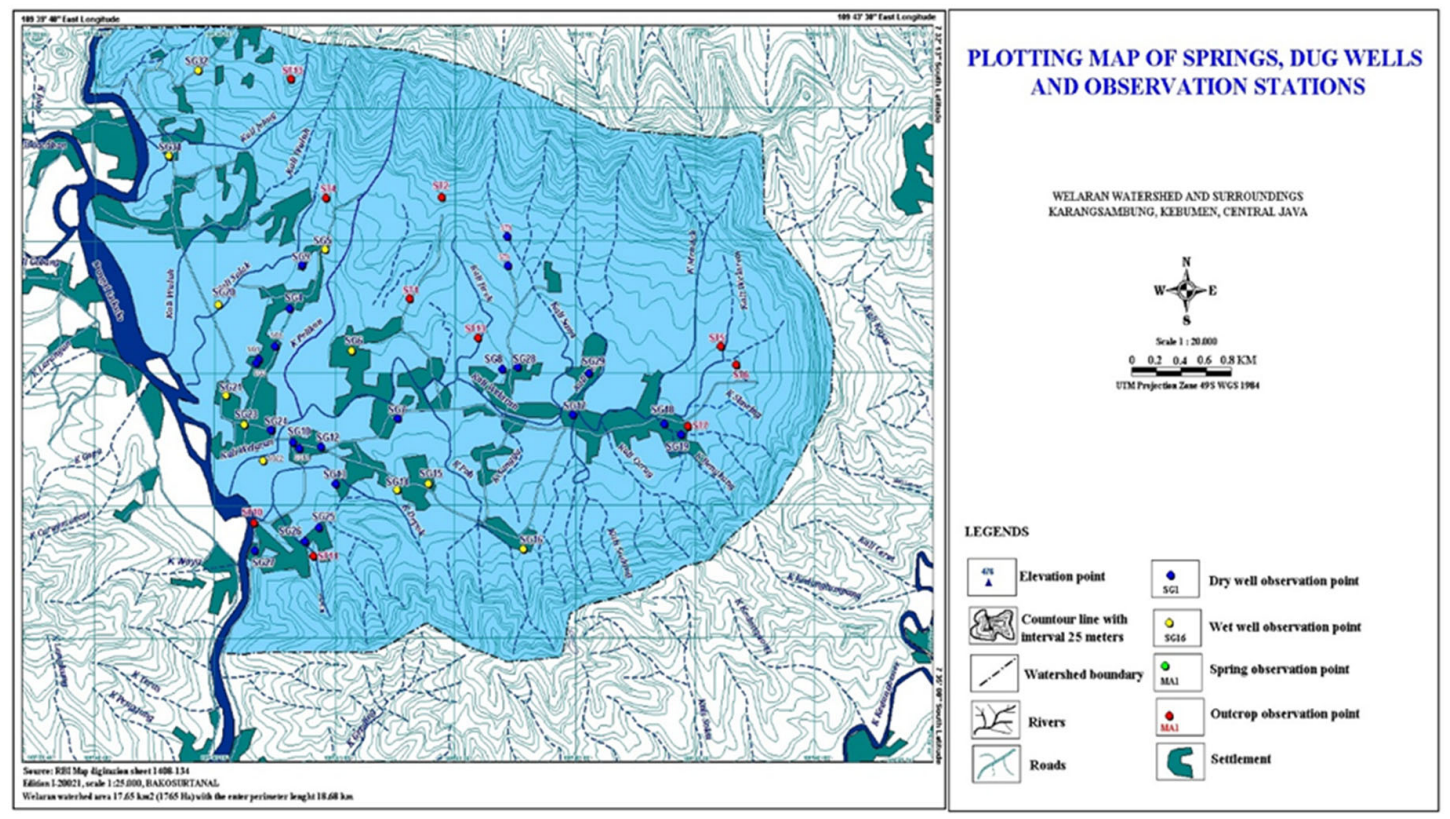

Figure 9. Map of wells, springs, and observation stations. Source of topography map: BAKOSURTANAL. 2001. 
groundwater flow in the Welaran Watershed consists of three main flow directions, from the north, east, and south (Figure 11). The main flow directions met in the Welaran valley and filled the dug wells in that location.

The depth of the groundwater table ranges from $1.5 \mathrm{~m}$ to $10.2 \mathrm{~m}$, with a mean of $4.53 \mathrm{~m}$, a median of $4.2 \mathrm{~m}$, and mode $2 \mathrm{~m}$. The $\mathrm{pH}$ value of spring water ranges from 7.11 to 8.18. The lowest $\mathrm{pH}$ value was recorded at MA2, while MA 10 recorded the highest $\mathrm{pH}$ value. The average $\mathrm{pH}$ value is 7.54. TDS in the springs ranges from 31 to $198 \mathrm{mg} / \mathrm{l}$. The lowest TDS value was recorded at MA11, while Ma 8 recorded the highest TDS. The mean value of TDS is $105.4 \mathrm{mg} / \mathrm{l}$. The water temperature in the springs ranges from $21.8^{\circ}$ to $30.9^{\circ} \mathrm{C}$. The lowest temperature was recorded at MA10, while the highest temperature was recorded at MA2. The average water temperature in the springs is $28.92^{\circ} \mathrm{C}$ (Figure 12). The $\mathrm{pH}$ value of dug well water ranged from 6.32 to 8.48, with the lowest $\mathrm{pH}$ value recorded at SG6 while the highest $\mathrm{pH}$ value recorded at SG12. The average $\mathrm{pH}$ value is 7.3. TDS value ranged from 29 to $438 \mathrm{mg} / \mathrm{l}$ with a mean TDS of 164.21, with the lowest TDS recorded at SG25 and the highest recorded at SG16 (Figure 13). In the dry season, the condition of the wells and springs is referred to the owner's information; that is 21 drypoints, 12 dug wells remain watery, while the springs flow throughout the year.

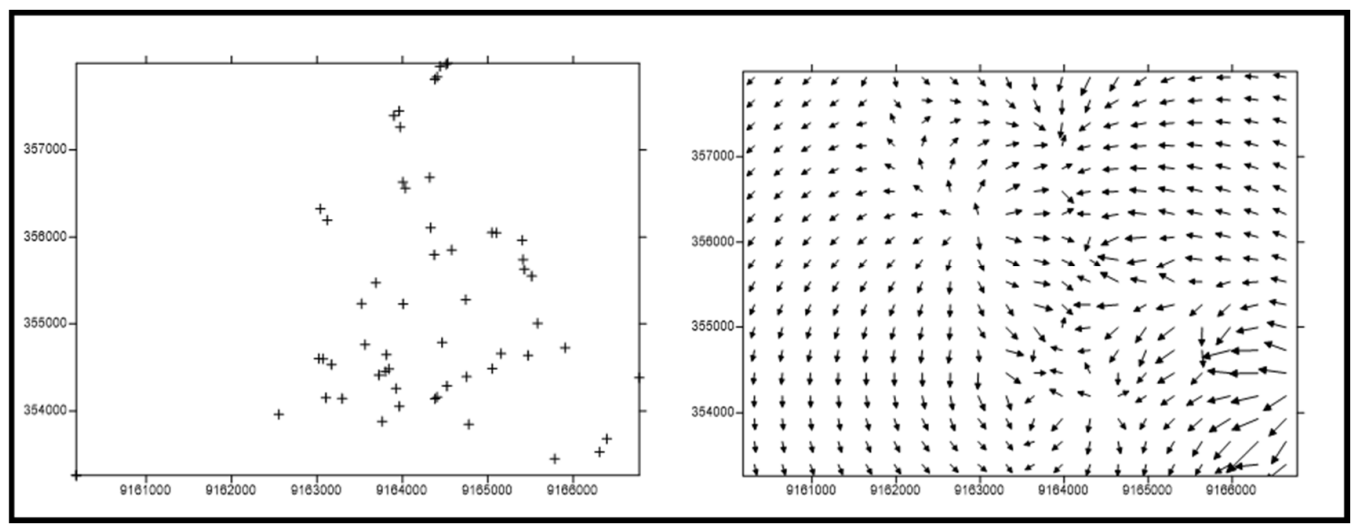

Figure 10. Left, plotting of dug wells and springs located in the Welaran valley; right, flownets of Welaran valley, both were made using Surfer.

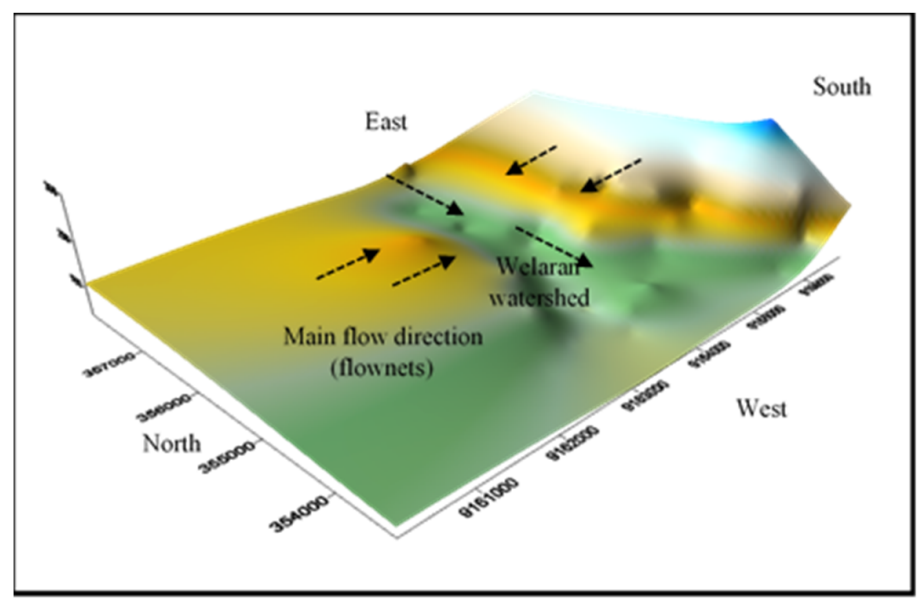

Figure 11. Illustration of the Welaran Watershed and direction of the main water flow direction that fills the Welaran Watershed. 


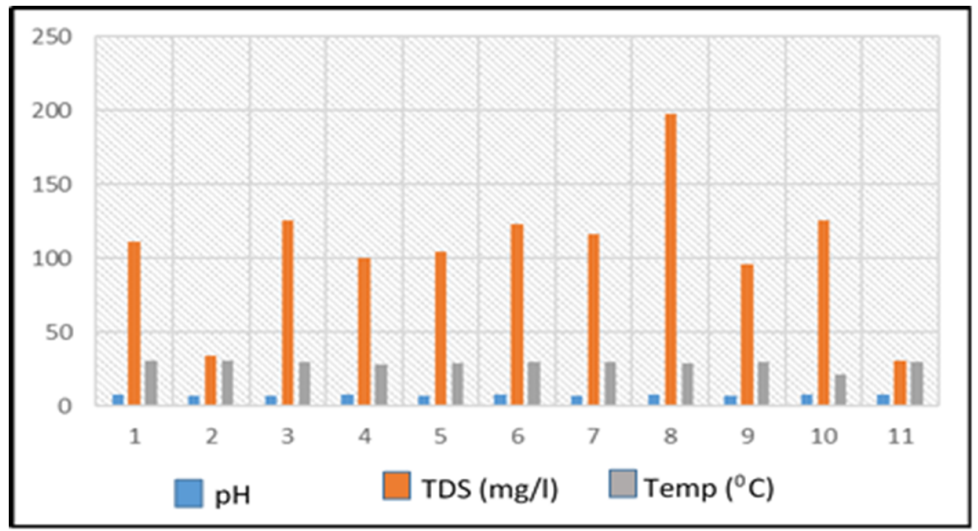

Figure 12. Histogram of $\mathrm{pH}, \mathrm{TDS}$, and temperature of springs water.

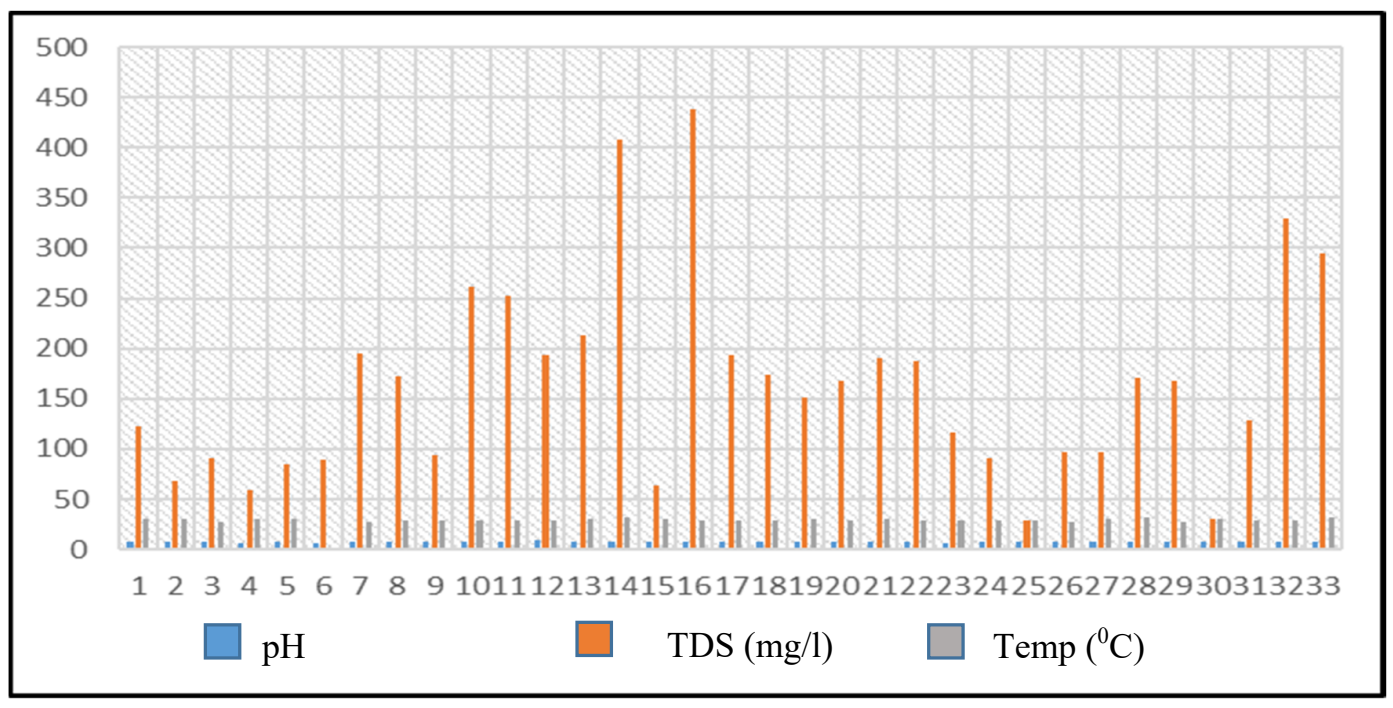

Figure 13. Histogram of $\mathrm{pH}$, TDS, and temperature of dug wells water.

\section{CONCLUSION}

The observed rainfall amount in the Welaran Watershed Karangsambung from September 2019 to September 2020 is $3586 \mathrm{~mm}$. Within that period, the water level in the Welaran river fluctuated depends on the monthly rainfall. The relationship between monthly precipitation and the water level of the Welaran river is $0.62 \%$. Therefore the rain that falls will be discharged as runoff instead of infiltrating the soil and rocks.

The Waturanda and Alluvial Formation are two formations with good porosity and permeability values in the study area; the total area distribution is $2.36 \mathrm{~km}^{2}$ (13.37\%). On the other hand, the rock units with poor porosity and permeability are the Karangsambung Formation, Totogan Formation, and Diabase Intrusion, distributed with a total area of $15.29 \mathrm{~km}^{2}(86.83 \%)$. The rocks in the Welaran Watershed are mostly rocks with poor porosity and permeability, which leads to low rainwater infiltration. Most rainwater that falls will become surface runoff. The hydrogeological character of the Welaran Watershed also causes the nature of the rivers in the 
Welaran Watershed to be intermittent (watery during the rainy season and dry during the dry season). The hydrogeological conditions and the character of the rivers in the Welaran Watershed also contribute to groundwater conditions in the Welaran Watershed. The Welaran Watershed is small with shallow depth, as seen from the average depth of the dug wells in the Welaran Watershed.

The groundwater flow patterns show three groundwater main flow directions: north, east, and south. Groundwater characteristics at dug wells indicate that groundwater is influenced by existing springs at the upstream Welaran Watershed.

\section{ACKNOWLEDGMENT}

The authors would like to thank BIKK and Research Center for Geotechnology - LIPI for giving permission and providing secondary data for this research and the field team who have assisted in collecting primary data in the field. We also appreciated reviewers and all parties involved in this writing and have provided suggestions and corrections.

\section{CONTRIBUTION STATEMENT}

NM is the main contributor of this paper, with support from RFL, BYC, and MPDH.

\section{REFERENCES}

Ansori. C, Sapri. H., 2002., Karakteristik Fragmen Endapan Olistrostome di Karangsambung, Kebumen. Buku Geologi Jawa Tengah - Yogyakarta, Publikasi Khusus IAGI Komda Jateng-DIY, 67-76.

Asdak. C, 1995. Hidrologi dan Pengelolaan Daerah Aliran Sungai., Gadjah Mada University Press., ISBN: 979-420-737-3.

Asikin., S, 1974. Evolusi Geologi Jawa Tengah ditinjau dari segi teori tektonik dunia yang baru. Doctoral Dissertation. ITB. Bandung. unpublished.

Asikin, S., Harsolumakso, A.H., Busono, H., Gafoer, S. 1992. Peta Geologi Lembar Banyumas., P3G Bandung.

Aulia. M. Rio., Putranto., T., Setyawan. R. 2020. Karakteristik Reservoir Berdasarkan Analisis Petrofisik Pada Formasi Baturaja, Lapangan Aulia, Cekungan Jawa Barat Utara. Jurnal Geosains dan Teknologi, 3 (1), 31 - 41. https://doi.org/10.14710/jgt.3.1.2020.31-41

Bakosurtanal. 2001. Peta RBI Lembar 1408-134, edisi I-2001, skala 1:25.000.

Balai Besar Wilayah Sungai Serayu-Opak. 2003. Identifikasi Potensi WS Serayu-Opak., Dirjen Sumber Daya Air, Kementrian PU.

Effendi., A. T., 1985. Peta Hidrogeologi Indonesia Lembar VI Pekalongan Jawa, skala 1:250.000., Direktorat Geologi Tata Lingkungan, Bandung.

Fetter., C.W. 2001. Applied Hydrogeology. Fourth Edition. Prentice-Hall. Inc. New Jersey.

Hadian. M. S. D, Mardiana. U., 2006. Sebaran Akuifer dan Pola Aliran Airtanah di Kecamatan Batuceper dan Kecamatan Benda Kota Tangerang, Propinsi Banten. Jurnal Geologi Indonesia 1 (3), 115-128.

Harsolumakso, A.H. 1996. Status Olistostrom di Daerah Luk Ulo, Jawa Tengah; suatu tinjauan stratigrafi, umur dan deformasi. Kumpulan Makalah Seminar Nasional Peran Sumberdaya Geologi dalam PJP II. 101-121.

Mareta. N, Hidayat. E., 2016. Hubungan Kondisi Geologi Lingkungan dan Lapisan Pembawa Airtanah Daerah Kebakalan dan Sekitarnya, Kebumen-Jawa Tengah. Jurnal Natural B, 3(4), 303-311.

Mareta. N, Raharjo. P.D., 2017. Analisis Morfologi dalam Penentuan Arah Pergerakan Patahan (Studi Kasus Daerah Kebakalan, Kebumen). Proceeding Seminar Nasional Kebumian Ke-10, Peran Penelitian Ilmu Kebumian Dalam Pembangunan Infrastruktur di Indonesia, 1956-1965.

Mareta.N, Ansori. C., 2020. Kajian Geologi Bawah Permukaan Formasi Karangsambung serta Formasi Totogan dan Hubungannya dengan Akuifer Airtanah di Desa Kalisana Kabupaten Kebumen., Bulletin of Scientific Contribution Geology, 18 (1), 45 - 56. 
Mulyana. D, 2008. Metode Penelitian Kualitatif: Paradigma Baru Ilmu Komunikasi dan Ilmu Sosial lainnya. Remaja Rosdakarya, Bandung.

Perlman, H., 2007. The Water Cycle, The USGS Water Science School. USGS.

Raharjo.P. D., Ansori.C, Widitanto. K, Winduhutomo. S., Purnami.D. N., Supriyanto.H., 2016. Morfometri dan Lingkungan Fisik DAS Lukulo Hulu Ditinjau Dari Pengaruhnya Terhadap Aliran Permukaan., Laporan Penelitian, BIKK-LIPI.

Sam Boggs, Jr. 2009. Petrology of Sedimentary Rocks, Second Edition. Cambridge University Press.

Setiawan.N. I., Yuwono. Y. S, Sucipta.IGD. E., 2011. The Genesis of Tertiary “Dakah Volcanics” in Karangsambung, Kebumen, Central Java. Majalah Geologi Indonesia 2(1), 29-44.

Sugiyono., 2005. Metode Penelitian Administrasi. Alfabeta, Bandung.

Suwarto.A.B, Hadian. M.S.D, Hendarmawan. 2018. Hidrogeologi CAT Batujajar Dengan Pendekatan Kajian Geologi dan Isotop 180 dan 2H, Studi Kasus: Kota Baru Parahyangan Padalarang. Seminar Nasional ke-II, Fakultas Teknik Geologi, Universitas Padjadjaran Bandung.

Todd, D.K. 1980. Groundwater Hydrology. John Wiley and Sons. New York.

Utaya, S., 1990. Pengantar Hidrogeologi: Konsep Dasar Hidrologi. Universitas Negeri Malang. 
Mareta et al. / Hydrogeological identification of the Welaran Watershed 